\section{From critique to practice: a response to Andrew Goffey}

\author{
Alex Nading
}

Goffey closes his essay by asking medical humanities scholars to give closer attention to 'the uncertainties operative within immunology considered as a practice'. ${ }^{1}$ Echoing Isabelle Stengers' call for a 'humour of truth' between humanities and natural sciences, Goffey encourages scholars in the medical humanities to embrace a 'shared perplexity' with working immunologists. ${ }^{2}$ This means that doing work in the medical humanities requires a recognition that many of the scientists with whom we work approach their research in full awareness that their perspectives are partial rather than totalising. They are perplexed, and we are perplexed.

After reading Goffey's paper, however, readers might be left wondering what, precisely, such perplexities might look like. Some may be technical/scientific, and some may be ethical/political. Those that seem to matter most to Goffey appear to be both at the same time, yet he refrains from offering a clear example. In this comment, however, I will attempt to apply Goffey's insights to the area of the scientific world I know best-the interdisciplinary study of dengue fever.

Although it is the most common mosquito-borne viral disease in the world, there is no drug or vaccine to cure or prevent dengue. One reason for this is that the disease can be caused by one of four distinct viral serotypes (known as Dengue 1, 2, 3 and 4). Each, on its own, can cause nausea, eye pain, and the extreme muscle and joint aches that give dengue its colloquial English name, 'break-bone fever'. Together, however, the serotypes are capable of playing an insidious trick on the immune system.

In a phenomenon known to immunology as 'original antigenic sin', bodies exposed to a single serotype (eg, to Dengue 1) develop antibodies and immunological 'memory' of the antigens dominant in that particular serotype. Problems arise when the same body confronts another serotype (say, Dengue 2). Dengue 2 may contain some of the same antigens as Dengue 1, but the antigens

Correspondence to Dr Alex Nading, School of Social and Political Science, University of Edinburgh,

15a George Square, Edinburgh EH8 9LD, UK; alex.nading@ed.ac.uk that were dominant in Dengue 1 are recessive in Dengue 2. An immune system already familiar with Dengue 1 can thus select antibodies that bind to receptors on the Dengue 2 viral monocytes, helping the virus replicate more quickly than it otherwise would. ${ }^{3}$ Bodies pay a hefty price for this. Secondary dengue infections can result in what is clinically called 'severe dengue', marked by internal plasma leakage and dangerously high fever. In short, as frontline health workers often say, 'Dengue makes you sick the first time, but it can kill you the second'.

The metaphor of the immune system 'sinning' raises both technical/scientific and ethical/political perplexities. For starters, agreement among scientists about original antigenic sin theory has never been uniform. Some suggest that the immune system's 'misrecognition' of antigens may sometimes be protective. Not everyone who is exposed to multiple serotypes develops severe dengue.

Although uncertainty remains about the immune system's role in severe dengue, a global public-private partnership called the Dengue Vaccine Initiative (DVI) has emerged, supported by the Rockefeller and Gates foundations. DVI has brought together for-profit pharmaceutical firms, universities and national health ministries to develop a tetravalent dengue vaccine-one that trains the immune system to protect the body against all four dengue serotypes. Given dengue's rapid global spread, the market for a vaccine is estimated to be in the billions of dollars.

Since DVI's inception, anxieties have arisen among dengue specialists. Vaccine research at times appears to be running ahead of basic immunological research. Dengue scientists thus find themselves obligated to police the borders of their disciplines for overblown or unsubstantiated claims that may benefit capital investors but undermine public health.

Goffey asks how the medical humanities should intervene in such perplexity. One approach might be to interrogate the 'original sin' metaphor. Critical theory has long been attuned to the moralising discourses of public health and medicine. ${ }^{4}$ Beyond engagement with metaphors, another approach, perhaps more in line with Goffey's intervention, would be to ask how scientists are engaging the forprofit vaccine development project. I have met few dengue scientists-even those most sceptical of for-profit medicinewhose work is not affected in some way by DVI's aggressive advocacy for vaccine development. For years, dengue was a disease that received little attention from either capital or philanthropy. Thanks to DVI, that has changed. The growing market potential for a dengue vaccine has facilitated new experimental explorations of the immune system, even as it has created new ethical conundrums. Many dengue scientists remain perplexed-in the sense that I think Goffey wants us to consider-about the dangers and the possibilities presented by DVI. ${ }^{5}$

A medical humanities intervention into this project would have articulating this perplexity-and making it productive for dengue prevention-as at least one objective.

To show how this might be done, let me join Goffey in drawing on Stengers. In her discussion of how sociologists of science might address the relationship between capitalism and theoretical physics, Stengers cautions against a 'vindictive morality' that imagines a future of pure science, free of the ethical compromises presented by entanglement with capital. Instead, she favours an approach that takes seriously the ethical and technical reasoning of the 'living physicist': one that 'celebrates' (in the sense of highlighting and calling analytical attention to) her 'anxiety'. Anxiety, Stengers argues, is part of a 'speculative' process-of imagining how worlds might be otherwise. ${ }^{5}$ The 'living physicist', like the living immunologist, cannot be morally vindictive. She must simply muddle through, neither content with the fact that capital overdetermines her work nor willing to abandon that work in the name of purifying practice.

Goffey is asking scholars in the medical humanities to make their engagements with immunology similarly 'anxious': to intervene in pressing medical problems without presuming that complete knowledge is ever possible. This would mean being willing to get involved in experiments and clinical interventions (even those in which capital has taken a heavy hand) more often than perhaps we have in the past. Such involvement would, of course, require generous interlocutors from the natural sciences-including immunology. But if Goffey is correct (as my admittedly limited experience suggests he may be), a sense of speculative anxiety 
already exists in the natural sciences. The fact that many bench researchers reflect, ethically, technically and politically, about the partiality of their perspective, is far from epiphenomenal to the everyday practice of science. Perhaps, it is the job of medical humanists to give voice to such reflections.

To do this job well, however, medical humanists must become comfortable with the idea that science is neither an explanatory device nor a device to be explained. Rather, like culture and politics (and vaccines and viruses), it is just one of the material-semiotic constructions that emerges out of human engagements in a perplexing world. To the extent that a recognition of this perplexity engenders more hopeful speculations, the 'humour of truth' that Goffey is after may be within reach. Yet, given the heated debate that has arisen around the entanglements of critical theory with environmental science and neurology (to name two recent examples) the path to humorous truth seems anything but clear. ${ }^{7-9}$

\section{Competing interests None.}

Provenance and peer review Not commissioned; internally peer reviewed.

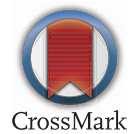

To cite Nading A. Med Humanit 2015;41:14-15.

Received 28 February 2015

Accepted 2 March 2015

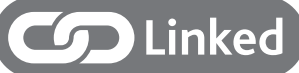

http://dx.doi.org/10.1136/medhum-2014-010661

Med Humanit 2015;41:14-15.

doi:10.1136/medhum-2015-010695

\section{REFERENCES}

1 Goffey A. Homo immunologicus: On the limits of critique. Med Humanit 2015;41:8-13.

2 Stengers I. The invention of modern science. Minneapolis, MN: University of Minnesota Press, 2000.

3 Host Response to the Dengue Virus. Scitable (Nature Education), $2014 \mathrm{http}: / /$ www.nature.com/scitable/ topicpage/host-response-to-the-denguevirus-22402106 (accessed 13 Dec 2013)

4 Peterson A, Lupton D. The new public health: health and self in the age of risk. London: Sage, 1996.

5 Nading A. Chimeric globalism: global health in the shadow of the dengue vaccine. Am Ethnol 2015;42 (2):356-70.

6 Stengers I. Cosmopolitics I. Minneapolis, MN: University of Minnesota Press, 2010:9-13.

7 Fortun K. From latour to late industrialism. Hau 2014;4(1):309-29.

8 Fitzgerald D, Callard F. Social science and neuroscience beyond interdisciplinarity: experimental entanglements. Theory Cult Soc 2015;32(1):3-32.

9 Stavrinakis A, Bennett G, Fearnley L, et al. Confusion, truth, and bureaucracy: a reply to Fitzgerald and Callard. Somatosphere. http://somatosphere.net/2014/ 12/confusion-truth-and-bureaucracy-a-reply-tofitzgerald-and-callard.html (9 Dec 2014). 